\title{
Design to social innovation: The systematization of a service elaborated based on a collaborative model to minimize a social demand in the environmental axis
}

\author{
Morgana Creuz Ganske ${ }^{1 a}$ e Marli Teresinha Everling ${ }^{2}$ \\ ${ }^{1}$ Univille, Design Department, Joinville/SC - Brazil \\ ${ }^{2}$ Univille, Design Department, Joinville/SC - Brazil
}

\begin{abstract}
This article discusses the use of collaborative models as a drive tool of projects focused in social innovation. The methodology consists of: bibliographical research, through consultations in several databases and the applied study case, in partnership with the Instituto Caranguejo de Educação Ambiental. The results are being used to implement the Rota do Mangue service, as well as in research and training activities that use design as transformation tool for individuals and cities.
\end{abstract}

Keywords. Social innovation, collaborative models, service design, new design.

\section{Design to social innovation}

The Brazilian scenario, in line with what is perceived in most countries around the world, reflects the gap between the current problems facing society and the standard of solutions that are offered. Traditional policy structures and tools, combined with the responses of the private market and public management, tend to offer old business models (that aim only for profit), instead of new challenges (focused on improving society). Because of this context, the awakening of a new way of thinking and idealizing solutions, combining traditional elements of production and consumption, with new techniques, tools and concepts linked to contemporary trends, called social innovation (MURRAY et al. 2010). It has a wide field of action, with challenges that need the persons' attention, to avoid the society collapse; It is quoted from the most noticeable to those that demand attention and research, such as social inequality, climate change, issues related to sustainability, public health, urban mobility, domestic violence, food production, childcare, the elderly, People in vulnerability, among others that are at the edge of the society chaos (MURRAY et al., 2010; ESCOLA DE DESIGN THINKING, 2016; BIGNETTI, 2011).

Social innovation has been discussed and reflected in various fields of academia and the market. Although most companies are oriented toward increasing competitive advantage, corroborating the scarcity of resources, governance through hierarchies, and increasing private value, social innovation has a concern for the transformation of behaviour and the awakening of

\footnotetext{
a Corresponding author: morganacreuz.mc@gmail.com
}

the belonging, with a focus on encouraging people to sow good practices, with the purpose of cultivating relationships, aiming to flourish in an environment more favourable to human relations. In this context, the link between social innovation and design one can be noticed, a rupture in the traditional models of action, changing the market focus for the well-being of society. When considering the Design' transversality, it is visualized as a facilitator to reality transformation of the current scenario. The Design essence is networking, which contributes to the challenges solution posed by multiple areas, contributing to the alignment with the social innovation premises, reinforcing the joint action of fields.

"Design is changing." This statement by Manzini and Meroni opens the foreword to Krucken's book (2009, p.13) entitled Design and Territory. Transformations related to the field of actuation, actors involved, forms and work tools, present a different look at the up to now linear process of Design. The authors state that there is no eccentricity in these issues, since society evolves and, similarly, the Design field has been changing. Design for social innovation in conjunction with other trends and events transcends traditional boundaries for years. It is perceived a differentiated and constantly growing look, aiming solutions to the challenges of society, as well as to the negative consequences of the Industrial Revolution and mass consumption. These demands redefine concepts, occasions and Design' purposes, since "the needs and characteristics of today's society ask the designers for a 
different performance from the past" (RIZZO, 2009 apud GAUDIO, OLIVEIRA, FRANZATO, 2014).

Manzini and Meroni (KRUCKEN, 2009, p.13) point to two contradictory aspects in the way in which Design has been reconfigured: "on the one hand, there is an accentuation of the spectacular nature of its interventions, the mediatic role of its actors, the Design that becomes an integral part of the communication system and with some designers who become part of the 'star system'. " Contrary to this line, one has the Design altering its configuration with focus in the improvement of the emergencies of the society. For the authors, "the 'new Design' adopts a systemic vision, which is confronted with the complexity of social networks, which develops a listening capacity that acts within the phenomena of creativity and diffuse entrepreneurship that characterize today's society. "The social transformations were not homogenous as well as the resistance of many professionals, to change their premises and to accept the challenges of the "new Design". The authors point out that partially, such resistance is due to the extreme complexity of this new culture of care and belonging. In this scenario, the collaborative/co-creative model in which the designer acts as a facilitator of the creation process gains space.

\subsection{Collaborative model as a tool}

Manzini (2008), in convergence with Sanders (2006), presents "a society in which 'all project', in which the capacities of Design are, by necessity, particularly diffuse." The author cites daily opportunities that need to be designed or redesigned, such as way of life, work, study, neighbourhood issues, associations, among others. Manzini (2008) argues that in this scenario the designers can help citizens in improving the solutions developed. This solution joint development is called co-design, that is, the collective creativity allied to the knowledge of the designer, who in this process acts as a facilitator (SANDERS, STAPPERS, 2008).

Collaborative proposes a new way of experiencing Design projects, requiring a systemic change that changes the ego-centered Design mode to the ecoecosystem (ESCOLA DE DESIGN THINKING, 2016) in which collective thinking prevails, built with different visions and experiences. Sanders (2006) argues that the participation of people who live or are part of the context, improve the development, since they are specialists of necessity; So, designers will not project to people, but with them "(ibid.). A differentiated role is attributed to the role of the designer: that of facilitator, defined by Ursini (apud MENA, 2016, web) as "an activity that assists workflows and collective and creative development to achieve a goal or solve a problem".

Manzini (2008) reflects on the bridges created by designers, linking society and technology, when discussing social innovation: the same bridge must be trafficked in a different sense, since "it is necessary to look for social innovation, identify promising cases, Design capabilities and abilities to design new artefacts and indicate new directions for technical innovation "(MANZINI, 2008, p.98). The author emphasizes that instead of diminishing the role of the designer in society, this approach awakens the valuation of the profession and the professional that will act in a collaborative way (with multiple actors of social innovation), contributing with knowledge, sensitivity, technique, creativity and everything where it is relevant. This new approach emphasizes the need for research in Design immersed in this scenario, considering the peculiarities and own knowledge. Papanek already in 1995 stated that "the function of the designer is to present people with options. These options should be real and meaningful, allowing people to fully participate in the decisions that concern them, and letting them communicate with designers and architects in search of solutions to their own problems, even by becoming their own designers "(Ibid., P.65). Lee, in 2012, places human-centered Design as a complementary approach to social innovation (macro view). Like Manzini (2008), the author considers the designer as a collective creation process facilitator. Thus, there is the adjacent development of solutions considering the collective creativity allied to the knowledge of the designer (SANDERS, STAPPERS, 2008). Per Sanders (2010, p.1), the culture of Design participation "usually involves many people, who have different backgrounds, experiences, interests, and roles within the project." In this way, a differentiated work format is required, encompassing specific tools, techniques and methods that are adapted to each new project and work team, to explore and capture the real insights of these multiple actors. The context presented by the author is common to what Minayo (2007) points out, the free methodology per the creativity and necessity of the researcher. It is believed that the methodology in Design projects must be more than a structured revenue, it must transpire the essence of the project, beyond the limits of methodological structures. The next topic presents a reflection on service design as an alternative focusing on sustainability.

\subsection{Sustainability-oriented service design}

The term service is derived from the Latin servitium, meaning the action of serving something or someone through a set of experiences. Service work logic reflects the dynamics of use versus ownership of a product. From this perspective, individuals are changed from owners to users, contributing to social reorganization and sustainability.

The services associated with Design knowledge are recent, while in the fields of administration, engineering 
and marketing have already been consolidated (MAGER, 2009). In the historical portrait of the area, the study of the science of services originated in the United States, while the theoretical development of the Design applied to the services sector was initiated in Europe (SACO, GONÇALVES, 2008 apud FREIRE, DAMAZIO, 2010). In this European scenario, Freire and Damazio (2010) present an avant-garde account of the theme in the field of Design, pointing out three fronts of study in the 1990s: (1) in Germany, with researchers Michael Erlhoff and Birgit Mager, at the University of Sciences Applied in Cologne; (2) in the UK, with Gillian Hollins and Bill Hollins; (3) in Italy, with Ézio Manzini, at the Polytechnic of Milan. Such precursors had different views of the area; Mager analysed the methodological Design process applied to the service sector, with emphasis on Design Thinking; Hollins and Hollins approached services from the point of view of Design management and Manzini saw services as an alternative with a focus on sustainability. Freire and Damazio (2010, p.04) affirm that from 1993 the configuration of services was changed, since Manzini "sees in the services the possibility of Design affect the society of consumption, no longer designing products to be owned by consumers but services that only stimulate the use of products, aiming at sustainability." The study of Service Design had a partial view of the project, in which each area was concerned with a part of the whole, the scope of Design being to think about the design of the scenario in which the relationship would take place. From the studies of Manzini, the vision becomes systemic, due to the integration of products, processes and points of contact. "The designer becomes involved in the process of delivering value to users" (Ibid.). In this initial approach, one can perceive the multidisciplinary of Service Design, covering distinct areas for study of the same center. Langenbach $(2008$, p.32) summarizes the introduction of Design principles in the service area as "the need to bring a more human vision to services, making the new technologies used by society aimed at improving the quality of Life, being then designed and organized to improve social relations."

In his studies on the theme of Design related to the service sector, Manzini (2007) presents to society a rupture in the traditional model, fated by the dominant market logic, which positions society as a passive consumer. Freire and Damazio (2010, p. 06) argue that "the role of institutions is to perform a series of activities to reduce the amount of effort, time and attention needed for individuals to receive the desired results." Such a position elucidates the social danger, because people also reduce the care with the environment they live. Manzini (2007) establishes a new possibility for Service Design, which acts as a creative platform, providing freedom for people to design solutions to their daily problems, inspired by the do it yourself trend. In the studies of Manzini (2008) it is noticed that the Service Design is worked among peers stimulating the co-design, contrary to most interventions in social innovation, that happen from the bottom up, or even the dominant logic of the society from above down. The Service Design is perceived as a tool to aid social innovation, focusing on the well-being of people and the environment in which they live. In continuity, it is presented as the design oriented to social innovation using a collaborative model as a tool, was applied to minimize a social demand of environmental axis in the city of Joinville.

\section{Project application: Rota do Mangue}

Social innovation and the new Design based on a collaborative model of action focused on the well-being of people, together with the Service Design were the premises for the Rota do Mangue systematization. The project challenge was realized in March 2016 when, in an informal meeting with Chico Lam (José F. P. Xavier) and Viviane Mendes, directors of Instituto Caranguejo de Educação Ambiental, they reported their anguish for the devaluation of the mangrove areas of the city of Joinville, as well as in the national panorama. They also shared their concerns about the people's lack of knowledge about the benefits of this ecosystem, the good functioning of the cities and the disregard of the rulers regarding the preservation and care of these areas. On this occasion, Chico Lam and Viviane pointed out some possibilities of improvement for the mentioned problems and started a collective brainstorming, aiming to raise new ideas to improve this challenge, as: the development of an application that interacts with the physical environment, a route to be experienced through active transportation such as a bicycle or canoe, a game to stimulate care of areas among other possibilities. It was perceived in this desire to soften a demand of society, a design possibility based on the theory of social innovation and correlated the discussions of Design as a tool in a world in transformation.

The project matured and was configured as a service to society, the Rota do Mangue. It was realized that this could be reapplied in any other region that face similar challenges, setting up a network service. The mangrove area of Babitonga Bay, in the Joinville region, under the denomination Rota da Babitonga, was defined as the scenario for the pilot project (from which the system would be designed). With the implementation of the partnership, it was established on Tuesday (morning period) as a day for a work meeting and, on a weekly basis, the project evolved from pre-project to development and defence of the service proposal. A structure with the key topics for design execution was elaborated, which was divided in seven steps: (1) mapping of the route; (2) visual identity; (3) physical structure; (4) digital structure; (5) replication strategy; (6) local income generation and; (7) extras to the service. For the project execution, the collaborative model was defined as a strategy of action. In these stages the 
availability and opening of the Institute's directors was fundamental considering that much of the information necessary for the proposal development was tacit, subjective and derived from the daily experience and the needs of the Institute. The next topic presents the collaborative model adopted for the development of route systematization.

\subsection{Collaborative model applied}

The deepening of the theoretical bases of Service Design, participation, collaboration and human-centered Design has portrayed a varied range of tools and work methods. The toolkit HCD - Human Centered Design of IDEO (2009) was consulted, the article: A Framework for Organizing the Tools and Techniques of Participatory Design, from Sanders; Brandt; Binder (2010); The book Universal Methods of Design by Martin and Hanington (2012); The book: Design Thinking, by Vianna, et al. (2012); The book: This is Design Thinking for Services, by Stickdorn and Schneider (2014); The online course and e-book: Service Design - creating a wow journey, from Descola (web) taught by William Spiga, the Service Design Tools (web) and Service Design Toolkit (web) sites among other LiveWork materials (Web), Escola de Thinking Design (web) and MJV (web) as examples of materials that have in essence the human being at the center of Design projects converging towards people participation, co-creation and design services. It was verified that most of the methodological structures are segmented from three to seven stages, varying the nomenclatures, but sharing the understanding and conception (BEST, 2006; MAGER, 2009; MIETTINEN \& KOIVISTO, 2009, apud STICKDORN; SCHNEIDER, 2014). The variation of terms is highlighted by Stickdorn and Schneider (2014, p.128) "identify - build - measure (ENGINE, 2009), insight - idea - prototype - delivery (LIVE WORK, 2009), discovery - concept - design construction - implementation (DESIGN THINKERS, 2009) ". Contributing to this survey, it was verified that for Stickdorn and Schneider (2014) it is structured in exploration, creation, reflection and implementation; For IDEO (2009) the listening, creating and implementing is visualized; For Vianna et al. (2012) are immersion, ideation and prototyping; For the United Kingdom Design Council (DESIGN COUNCIL, web) has the discover, define, develop and deliver. The aim was to name the steps of each author, aiming to demonstrate that the concept is similar in both approaches, what differs is the nomenclature used.

Building on the design of a Service Design methodology, Stickdorn and Schneider (2014) emphasize the itinerant factor that in essence symbolizes the non-linearity of the project and continues its explanation, stating that "this means that at every stage of the design process of a service, it may be necessary to go back a step, or even start from scratch. The only (but very important) difference is in making sure you learn from the errors of the previous iteration. The authors emphasize that with each new service, it is necessary to analyse the context and think about the process adding and removing steps, since each project has unique characteristics;

Considering the methodology as the path of thought, which is free and flexible per the researcher's creativity and need, the highlighted tools were not used in their entirety (MINAYO, 2007). For the systematization of the Rota do Mangue service and creation of a replication strategy of the project, the base structure of Stickdorn and Schneider (2014) was used due to the specificity of this one for the construction of service projects. The tools used in the accomplishment of the steps were: map of stakeholders, value relation, map of empathy, narrative of personas, brainstorming, ideas generation, co-creation, experience, map of users' journey and service blueprint. Collaboration was crucial to the evolution of the project by providing multiple visions with a focus on dynamism, innovation and focus on the design challenge.

\section{Final Considerations}

The transformations experienced by society invite us to rethink it in the most diverse spheres. Design is still perceived as an area of knowledge linked to the development of products with a focus on mass consumption and its potential for collaborative and participatory action alongside other areas of knowledge is often ignored. The Design associated to social innovation presents a breakdown of paradigms when proposing a society focused on continuous improvement; A new way of thinking, living and establishing relationships that brings answers to many challenges of life in society.

There was an objectives convergence between the collaborative model and Service Design, co-creation, focus on the human being and other concepts that reinforce social innovation. Timidly, there is an adhesion to this movement that visualizes the problems of daily life, opportunities to minimize impacts and contribute to a more human, intelligent and sustainable city. The Service Design in a creative and innovative way has given the opportunity to development of solutions that benefit the whole, balancing relations of need and consumption for a sustainable bias. The results are being used in the implementation of the Rota do Mangue and in parallel study on the new Design and how this can become a tool for social innovation. 


\section{References}

BIGNETTI, Luiz Paulo. As inovações sociais: uma incursão por ideias, tendências e focos de pesquisa. Ciências Sociais Unisinos 47(1):3-14, janeiro/abril 2011 Disponível em: <goo.gl/MpFdgr $>$. Acesso em: 17 jun. 2016.

DESCOLA. Curso on-line de Design de Serviços: Criando uma jornada WOW, professor William Spiga. Disponível em: <goo.gl/mkv3yj>. Acesso em: 01 nov. 2016.

DESCOLA. Design de serviços (criando experiências incríveis). Disponível em: <https://goo.gl/oZ0jY6>. Acesso em: 28 out. 2016.

DESIGN COUNCIL. A study of the design process. Disponível em: < https://goo.gl/HQESCE > . Acesso em: 03 ago. 2016.

ESCOLA DE DESIGN THINKING. 2016. E-book inovação social. Disponível em:

$<$ https://goo.gl/vBbX2d>. Acesso em: 11 mar. 2016.

ESCOLA DE DESIGN THINKING. 2016. E-book mapa de stakeholders. Disponível em:

$<$ https://goo.gl/edyYEH>. Acesso em: 11 mar. 2016

ESCOLA DE DESIGN THINKING. Disponível em: $<$ http://escoladesignthinking.echos.cc $>$. Acesso em: 28 jul. 2016.

FREIRE, K. DE M.; DAMAZIO, V. Design de serviços: conceitos e reflexões sobre o futuro da disciplina. $9^{\circ}$ Congresso Brasileiro de Pesquisa e Desenvolvimento em Design. Anais... São Paulo: Blücher; Universidade Anhembi Morumbi, 2010

GANSKE, Morgana Creuz. Design para Inovação Social: Uma Perspectiva sobre a Atuação do Designer em um Mundo Complexo, em uma Aplicação Prática Denominada Rota do Mangue. Orientadora: Profa. Dra. Marli Teresinha Everling. Disponível em:

$<$ https://goo.gl/SRHcqK>.Acesso em: 15 fev. 2017.

GAUDIO, Chiara Del; OLIVEIRA, Alfredo Jefferson de; FRANZATO, Carlo. O tempo no design participativo, p. 957-969 . In: Anais do $11^{\circ}$ Congresso Brasileiro de Pesquisa e Desenvolvimento em Design, Blucher Design Proceedings, v. 1, n. 4. São Paulo: Blucher, 2014.

IDEO. Human Centered Design Toolkit. 2009. Disponível em < https://goo.gl/BPf3T > Acesso em: 08 nov. 2015.
KRUCKEN, Lia. Design e território: valorização de identidades e produtos locais. São Paulo: Studio Nobel, 2009.

LANGENBACH, M. L. Além do apenas funcional inovação social e design de serviços na realidade brasileira. 2008. 123 f. Dissert. (Mestrado) Engenharia de Produção, UFRJ, 2008.

LEE, Jung-Joo; Against Method: The Portability of Method in Human Centered Design. Helsinki: AaltoUniversity.2012.

LIVEWORK. Disponível em: <https://goo.gl/UFY2wt> Acesso em: 15 out. 2016.

MAGER, Brigit. Service design as an emerging field. In: (Ed.). Designing services with innovative methods. Keuruu: University of Art and Design Helsinki, v.1, 2009. Service Design as an emerging field, p.28-43.

MANZINI, Ezio. 2008. Design para a inovação social e sustentabilidade: comunidades criativas, organizações colaborativas e novas redes projetuais. Coordenação de tradução Carla Cipolla. Caderno do Grupo de Altos Estudos, VI. Rio de Janeiro, Programa de Engenharia de Produção da Coppe/UFRJ,vol. I.

Design in a changing, connected world. Strategic Design Research Journal, São Leopoldo, RS, v.7, n.2, maio/ago. 2014. Disponível em: $<$ https://goo.gl/Nxnzk0>. Acesso em: 20 jul. 2016.

Design for sustainability. How to design suistainable solutions. jan 31, p.1-13. 2007.

MARTIN, B; HANINGTON, B. Universal Methods of design: 100 ways to research comples problems, develop innovative ideas and design effective solutions. Beverly: Rockport Publishers, 2012.

MENA, Isabela. (2016) Verbete Draft: o que é facilitador. Disponível em: <https://goo.gl/ dOUcmD>.Acesso em: 22 out. 2016.

MINAYO, Maria Cecília de Souza. O Desafio do Conhecimento-Pesquisa Qualitativa em Saúde. São Paulo: Hucitec, 8a edição, 2004.

MJV. O que é Design de Serviços? (2016). Disponível em: <http://blog.mjv.com.br/o-que-e-design-deservicos>.Acesso em: 28 out. 2016.

MURRAY, R. et al. 2010. The Open Book of Social Innovation. London, NESTA/The Young Foundation. Disponível em: $<$ https://goo.gl/4k55rf $>$. Acesso em: 02 jun. 2016. 
PAPANEK, Victor. Design for the real world: human ecology and social change. New York: Pantheon Book, 1971.

PAPANEK, Victor. Arquitectura e design: ecologia e ética. Lisboa: Edições 70, 1995.

SANDERS, Elizabeth B.-N. (2006) Design Serving People. In: Salmi, E., \& Anusionwu, L. (Eds.) Cumulus Working Papers, Copenhagen, University of Art and Design, Helsinki, Finland, 28-33.

SANDERS, Elizabeth B.-N. \& STAPPERS, Pieter Jan. Co-creation and the new landscapes of design. $\mathrm{Co}-$ design. 4(1), 2008, pp. 5-18.

SANDERS, Elizabeth B.-N, BRANDT, Eva; BINDER, Thomas. Framework for Organizing the Tools and Techniques of Participatory Design. In: Proceedings of the 11th Biennial Participatory Design Conference, p. 195-198: ACM. Brandt and T. Binder (2010), Sydney, Australia. Disponível em: <https://goo.gl/qGrWdJ >. Acesso em: 25 jun.2016.

SERVICE DESIGN TOOLS. Disponível em: $<$ servicedesigntools.org > . Acesso em: 15 out. 2016.

SERVICE DESIGN TOOLKIT. Disponível em: $<$ www.servicedesigntoolkit.org $>$. Acesso em: 15 out. 2016.

STICKDORN, Marc; SCHNEIDER, Jakob. Isto é Design Thinking de Serviços: Fundamentos, Ferramentas, Casos. 1. ed. Porto Alegre: Bookman, p.168, 2014.

VIANNA, Maurício; et al. Design Thinking Inovação em negócios. Rio de Janeiro, RJ: MJV Press, 2012.

XAVIER, José Francisco Peligrino; MENDES, Viviane Cris. Entrevista concedida a Morgana Creuz Ganske. Joinville, 6 abr. 2016. 